\title{
Observations on the endemicity of plague in Karatu and Ngorongoro, northern Tanzania
}

\author{
B.S. KILONZO ${ }^{*}$, T.J. MBISE2, D.C. MWALIMU ${ }^{3}$ and L. KINDAMBA ${ }^{1}$ \\ ${ }^{1}$ Sokoine University of Agriculture, Box 3110, Morogoro, Tanzania \\ ${ }^{2}$ Tropical Pesticides Research Institute, Box 3024, Arusha, Tanzania \\ ${ }^{3}$ Ministry of Health, Box 9083, Dar es Salaam, Tanzania
}

\begin{abstract}
Commensal and field rodents and wild small carnivores were live-trapped in five villages of Karatu district and one settlement in the Ngorongoro Conservation Area in Ngorongoro district in Tanzania. Blood samples were taken and serologically tested for plague, using the Blocking ELISA technique. Some domestic dogs and cats in the Karatu villages were aseptically bled and similarly tested for plague. Fleas were collected from the examined animals and from randomly selected residential houses. A total of 241 rodents, 1 Crocidura spp, 43 dogs, 12 cats and 4 slender mongooses were involved in the survey. Of the rodents, $14.5 \%$ were infested with fleas, which comprised of Xenopsylla brasiliensis (45.8\%) and Dinopsyllus lypusus (54.2\%), with an overall population density of 0.2 fleas/animal. Thirty one (72.1\%) of the dogs were infested with fleas, all of which were Ctenocephalides spp. Thirty five (63.3\%) houses were infested with fleas whose population was composed of Ctenocephalides spp, Pulex irritans, Tunga penetrans and Echinophaga gallinacea. Infected rodents were found in all the villages while the infected dog was found at Rhotia-Kati. Nineteen (11\%) of the rodents and one (2\%) dog harboured specific plague antibodies. It was broadly concluded that sylvatic plague was endemic in Karatu district and Ngorongoro Conservation Area and that outbreaks of the disease can occur in the area any time if and when relevant conditions become favourable. Prompt application of appropriate preventive and control measures and survey for substantiating the status in the Lake Manyara National Park, which is adjacent to some of the infected villages, are recommended.
\end{abstract}

Key words: Plague, fleas, rodents, carnivores, Tanzania

\section{Introduction}

Plague has been an important health problem in various parts of Tanzania since its introduction into the country in the late $19^{\text {th }}$ century. Most foci were established in the southwestern, northern, central and northeastern zones of the country during the $20^{\text {th }}$ century. These include Iringa-Rural, Kagera, Musoma, Singida, Kondoa, Rombo, Hai, Arumeru, Mbulu, Same and Lushoto districts (Msangi, 1968; Kilonzo \& Msangi, 1991) All the foci have experienced several outbreaks of the disease at one time or another, and caused substantial losses of human lives (Kilonzo, 1992).

Most foci of the disease in Tanzania have been inactive for almost three decades and are considered to be potentially quiescent. In view of the reemergence nature of plague however, recurrence of outbreaks at these foci cannot be ruled out. Indeed plague outbreaks have been reported in places where the disease had been inactive for many years. The 1994 outbreak of plague in India for example, occurred after nearly 30 years of quiescence (WHO, 1995). Likewise, Malawi which is one of the few countries in tropical Africa where plague foci are limited, experienced an outbreak of the disease in 1994 after 31 years of quiescence (Kilonzo, 1999). Similarly, plague outbreaks have occurred in some established foci in Tanzania which were inactive for many years. The 1972 outbreak in Hai district for example occurred after the disease had been latent in the focus for 16 years (Kilonzo, 1981; 1984). Kilonzo \& Temu, 1994).

The most recently established focus of plague in Tanzania is in Lushoto district. The initial outbreak of the disease in the district occurred in 1980 and involved 49 recorded cases with 11 (22.4\%) deaths (Kilonzo \& Mhina, 1982). Studies carried out during and soon after that outbreak suggested that the disease was probably due to introduction from Kenya where it was then prevalent or the South Pare mountains in Tanzania which harbour an endemic focus of the disease and which lie in the same geographical and climatic belt as Lushoto district (Kenya, 1978; Kilonzo \& Mhina, 1982). Indeed the index case had been visiting both places for business and social activities prior to his illness and consequent death. However, possible existence of a local endemic focus in the district that was latent for many years prior to the 1980 outbreak, cannot be ruled out.

Karatu district which was previously part of Mbulu district, experienced an outbreak of human plague for the first time in 1996 and involved 186 clinically suspected cases with $12(6.5 \%)$ deaths (Kilonzo \& Mbise, 1998). This outbreak affected six villages (Tloma, Ayalabe, Rhotia-Kati, Kilimatembo, Kambi ya Simba and Slahoma) and was allegedly caused by transportation of infected materials from Lushoto where the disease had been prevalent since 1980, and from where fruits were being transported to Karatu and elsewhere in the country for sale. Like 
Lushoto district, possible presence of an inactive sylvatic focus of the disease in the district or introduction of the pathogen from the neighbouring Mbulu district which harbours a long-standing focus (Kilonzo \& Mtoi, 1983), cannot be ruled out. A similar outbreak occurred in the same area in 1997 and involved 11 cases/suspects with 2 (18.2\%) deaths (Kilonzo \& Mbise, 1998). The two outbreaks in consecutive years caused substantial concern among various authorities, scientists and communities, and a need to investigate and establish endemicity levels and risks of more outbreaks of the disease in the district and the neighbouring Ngorongoro Conservation area was felt desirable. Such data would serve as a basis for making sound recommendations for developing and implementing large-scale control/preventive measures of the disease in the area.

Preliminary investigations were carried out in August 1998 and observations indicated that there were no immediate risks of an outbreak in the area. Despite these observations however, presence of endemic plague was not ruled out due to the fact that only a few rodents were serologically tested for the infection and that the sensitivity of the passive haemmaglutination test used is limited (Kilonzo \& Mbise, 1998). Further surveys which would involve adequate numbers of rodents, small carnivores and fleas, and use of more sensitive serological techniques, were therefore recommended. In fulfilment of such recommendation, zoological, entomological, bacteriological and serological surveys were carried out in July 2004, and the aim of this paper is to report the observations made in such surveys.

\section{Materials and Methods}

\section{Study area}

The surveys were carried out at the villages of Slahoma, Kambi ya Simba, Rhotia-Kati, Tloma, and Kambi ya Nyoka (all bordering Ngorongoro Conservation forest), and Makao. The latter is based in the Ngorongoro Conservation Area and is the headquarters of the Ngorongoro Conservation Area Authority (NCAA). Slahoma, Kambi ya Simba, Rhotia-Kati and Tloma were involved in the previous outbreaks of the disease.

\section{Procedures}

Live trapping of wild and commensal rodents was carried out using Sherman traps baited with peanut butter. An average of 120 traps (60 in houses and 60 in nearby fields) were deployed per trap night for 3 consecutive nights in each village.

The choice of houses was randomly selected from a list provided by village leadership, and informed consent of house owners was sought prior to setting traps. Choice of areas for trapping field rodents and carnivores was based on, among other things, security of traps and proven activities of such animals. Each captured rodent was carefully transferred to a cloth bag and then to a screw-capped museum jar containing pieces of cotton wool soaked in ether in order to anaesthetise both the animal and its ectoparasites. The former was then bled from the orbital vein using a plain capillary tube and a screw-capped micro-tube. Occasionally blood was obtained by heart puncture using disposable syringes and needles. Flea ectoparasites were removed, preserved, processed and identified as described before (Kilonzo \& Mhina, 1983). All the animal carcasses were identified, sexed and autopsied. Impression smears were prepared from spleen, liver, heart and lung, and processed for examination and consequent diagnosis of suspicious plague bacilli as described elsewhere (Kilonzo \& Mtoi, 1983).

About $1-2 \mathrm{ml}$ of venous blood was aseptically collected from domestic dogs and cats whose owners willingly brought them to the agreed site and offered good co-operation. Wild carnivores were similarly treated after being anaesthetized. All the blood samples (rodents and carnivores) were left at room temperature overnight for spontaneous separation of serum. Occasionally, the latter was separated by centrifugation at $4000 \mathrm{rpm}$ for ten minutes. The sera were then kept at $0^{\circ} \mathrm{C}$ in the field and at $-70^{\circ} \mathrm{C}$ upon returning to the Central Laboratory in Morogoro. Finally, they were tested for specific anti-plague antibodies using the Blocking ELISA technique. Flea ectoparasites of the carnivorous animals were collected, preserved, processed, identified and counted as described for rodent-fleas. House fleas were trapped in randomly selected residential houses after obtaining informed consent of the relevant residents. The process was accomplished by using light traps and techniques described by Kilonzo (1977). Trapping in each selected house was carried out for three consecutive nights while collection of the captures and replenishment of kerosene in the traps were done every morning. The captures were treated as described for animal fleas above. 


\section{Results}

Table 1: Numbers and species of rodents captured in villages in Karatu and Ngorongoro

\begin{tabular}{|c|c|c|c|c|c|c|c|c|}
\hline \multicolumn{9}{|c|}{ Village } \\
\hline Rodent Species & Slahamo & $\begin{array}{l}\text { Kambi ya } \\
\text { Simba }\end{array}$ & Rhotia-Kati & Tloma & $\begin{array}{c}\text { Kambi ya } \\
\text { Nyoka }\end{array}$ & Makao & Total & $\%$ \\
\hline M. natalensis & 43 & 14 & 9 & 17 & 28 & - & 111 & 45.9 \\
\hline R. rattus & 10 & 1 & 8 & 2 & 2 & 32 & 55 & 22.7 \\
\hline L. striatus & 3 & - & 2 & - & 7 & 36 & 48 & 19.8 \\
\hline Leggada (M) min & 1 & - & - & - & 11 & - & 12 & 5 \\
\hline Praomys spp. & - & - & - & - & 3 & 2 & 5 & 2.1 \\
\hline Lophuromys spp. & - & - & - & - & - & - & 2 & 0.8 \\
\hline G. dolichurus & 1 & 1 & - & - & - & - & 2 & 0.8 \\
\hline A. nairobe & - & 1 & - & - & - & 1 & 1 & 0.4 \\
\hline Graphiurus spp. & - & - & - & - & - & 1 & 1 & 0.4 \\
\hline Crocidura spp. & - & - & - & - & - & 2 & 1 & 0.4 \\
\hline Unidentified species & 2 & - & - & - & - & & 4 & 1.7 \\
\hline Total & 60 & 17 & 19 & 19 & 51 & & 242 & 100 \\
\hline
\end{tabular}

Table 2: Species, numbers and population densities of rodent fleas in Karatu and Ngorongoro

\begin{tabular}{|c|c|c|c|c|c|c|c|}
\hline \multirow[t]{2}{*}{$\begin{array}{c}\text { Species of } \\
\text { Host }\end{array}$} & \multirow[t]{2}{*}{$\begin{array}{c}\text { No. } \\
\text { examined }\end{array}$} & \multirow[t]{2}{*}{$\begin{array}{l}\text { No. }(\%) \\
\text { infested }\end{array}$} & \multicolumn{2}{|c|}{$\begin{array}{l}\text { Species and numbers (\%) } \\
\text { Of fleas }\end{array}$} & \multirow[t]{2}{*}{ Total } & \multirow[t]{2}{*}{$\begin{array}{l}\text { Total } \\
\text { index }\end{array}$} & \multirow[t]{2}{*}{$\begin{array}{c}\text { infested } \\
\text { index }\end{array}$} \\
\hline & & & $\begin{array}{c}X . \\
\text { brasiliensi } \\
s \\
\end{array}$ & D. lypusus & & & \\
\hline M. natalensis & 111 & $20(18.0)$ & 10 & 16 & 26 & 0.2 & 1.3 \\
\hline R. rattus & 55 & $7(12.7)$ & 8 & 2 & 10 & 0.2 & 1.4 \\
\hline L. striatus & 48 & $5(10.4)$ & 4 & 3 & 7 & 0.1 & 1.4 \\
\hline M. minutoides & 12 & 0 & - & - & - & - & - \\
\hline Praomys spp. & 5 & 0 & - & - & - & - & - \\
\hline Lophuromys spp. & 2 & $2(100)$ & - & 4 & 4 & 2.0 & 2.0 \\
\hline G. dolichurus & 2 & 0 & - & - & - & - & - \\
\hline A. nairobe & 1 & 0 & - & 1 & 1 & 1.0 & 1.0 \\
\hline Graphiurus spp. & 1 & 0 & - & - & - & - & - \\
\hline Crocidura spp. & 1 & 0 & - & - & - & - & - \\
\hline Unidentified & 4 & $1(25.0)$ & - & - & - & - & - \\
\hline Total & 242 & $35(14.5)$ & $22(45.8)$ & $26(54.2)$ & 48 & 0.2 & 1.4 \\
\hline
\end{tabular}

* Insectivora; ** Specimen morphology badly damaged by carnivorous insects.

A total of 241 rodents and one insectivore (Crocidura spp) were collected from the study villages. Of these, Mastomys natalensis were the majority and comprised of $45.9 \%$ of total captures, followed by Rattus rattus (22.7\%) and Lemniscomys striatus (19.8\%) (Table1). The former two species were captured in all the surveyed villages except Makao, a settlement within the Ngorongoro Conservation Area. In this area, $L$. striatus which is a common field/wild species in many parts of the country was captured both in the field and in houses.

A total of 53 fleas were collected from $14.5 \%$ of the captured rodents and insectivore. Of these, 48 were processed and identified as Xenopsylla brasiliensis (45.8\%) and Dinopsyllus lypusus (54.2\%) (Table 2). Five fleas were damaged while being transported from the study area to the Central
Laboratory.

The total and infested flea indices were fairly low (0.2 fleas/animal and 1.4 fleas/infested animal), respectively.

Fifty-nine small carnivores comprising of 43 (72.9\%) Canis familiaris, 12 (20.3\%) Felis catus and $4(6.8 \%)$ Hepestia sanguinea were involved in the study (Table 3). The carnivores were collected at Kambi ya Simba (C. familiaris $=13 ; F$. catus $=4 ; H$. sanguinea $=1)$, Slahamo $(C$. familiaris $=4 ; F$. catus $=$ 1), Rhotia-Kati (C. familiaris $=17 ; F$. catus $=5$ ), Tloma $(C$. familiaris $=2)$, Kambi ya Nyoka $(C$. familiaris $=7 ; F$. catus $=2)$ and Makao $(H$. sanguinea $=$ $3)$. Of the examined carnivores, $31(72.1 \%) C$. familiaris were infested with 517 fleas, all of which were Ctenocephalides spp. Likewise, light traps were set in 42 houses and $35(63.3 \%)$ of them were infested with fleas which comprised of four species (Table 3). 
Table 3: Species and population densities of fleas collected from small carnivores and houses

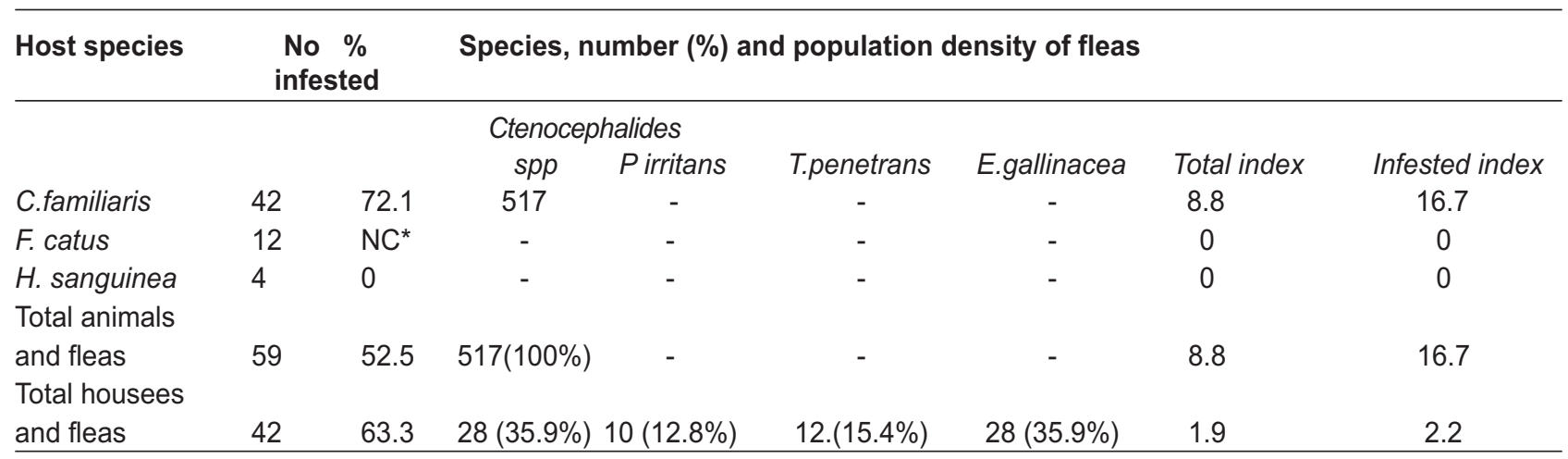

$\mathrm{NC}^{*}=$ Fleas were not collected as the animals became fierce after brushing with ether

Table 4: Results of ELISA tests on rodent and carnivorous sera

\begin{tabular}{lcccc}
\hline Species & No. tested & No. positive & \% positive & Titre \\
\hline M. natalensis & 74 & 7 & 9.5 & $1: 4-1: 16$ \\
R. rattus & 49 & 4 & 8.2 & $1: 16-1: 64$ \\
L. striatus & 34 & 7 & 20.6 & $1: 4-1: 16$ \\
Praomys spp. & 4 & 0 & 0 & - \\
M. minutoides & 3 & 0 & 0 & - \\
Lophuromys spp & 2 & 0 & 0 & - \\
G. dolichurus & 1 & 1 & 100 & - \\
A. nairobe & 1 & 0 & 0 & - \\
Unidentified rodents & 4 & 0 & 0 & $1: 16-1: 64$ \\
Total rodents & 172 & 19 & 11.0 & $1: 16$ \\
C. familiaris & 38 & 1 & 0 & - \\
F. catus & 9 & 0 & 0 & $1: 16$ \\
H. sanguinea & 2 & 0 & 2.0 & $1: 4-1: 64$ \\
Total carnivores & 49 & 1 & 9.0 & - \\
Total & 221 & 20 & & \\
\hline
\end{tabular}

A total of 172 and 49 sera of rodents and carnivores, respectively were subjected to Competitive Blocking ELISA tests. Of these, $19(11.0 \%)$ rodents and one (2.0\%) domestic dog were positive for specific antiF1 plague antibodies at titres ranging from 1:4 to 1:64 (Tables 4 and 5). The positive rodents were $M$. natalensis $(9.5 \%)$, R. rattus (8.2\%), L. striatus $(20.6 \%)$ and $G$. dolichurus (100\%). Positive rodents were found in all the study villages including Makao (Table 5). The positive dog was examined at Rhotia-Kati where $22.2 \%$ of the rodents were positive.

Organ impression smears were examined for 241 rodents and one insectivore captured in all the study villages. Of these, one animal (M. natalensis) from Kambi ya Nyoka and two ( $R$. rattus and L. striatus) from Makao contained bipolar-staining bacilli. Trypanosoma lewisi, other species of bacilli and Toxoplasma spp. were also observed in organs of 16 , 13 and 1 animals, respectively.

Table 5: Status of plague infections among natural reservoirs and carriers in Karatu and Ngorongoro

\begin{tabular}{lccc}
\hline Village or locality & No. rodents tested & $\begin{array}{c}\text { No rodents } \\
\text { positive }\end{array}$ & \% rodent positive \\
\hline Slahoma & 36 & 5 & 13.9 \\
Rhotia-Kati & 18 & 4 & 22.2 \\
Kambi ya Simba & 15 & 2 & 13.3 \\
Kambi ya Nyoka & 31 & 1 & 6.5 \\
Tloma & 16 & 1 & 6.3 \\
Makao & 56 & 5 & 8.9 \\
Total & 172 & 19 & 11.0 \\
\hline
\end{tabular}




\section{Discussion}

The demonstration of specific anti-plague antibodies in $11 \%$ of rodents and $2 \%$ of small carnivores in various villages and the adjacent Ngorongoro Conservation Area strongly suggests that the animals have been exposed to Yersinia pestis, the plague pathogen, in the recent past. Since home range of rodents is known to be fairly short as previously demonstrated in Muheza, Morogoro and Lushoto districts (Kilonzo, 1984; Leirs, 1992; R.H. Makundi, unpubl.), the current observations can be justifiably interpreted to suggest that the animals were exposed to the plague causative agent locally, and that the disease is latently persistent in the area.

The observed large percentages of $L$. striatus, $R$. rattus and $M$. natalensis harbouring specific plague antibodies, and the absence of rodent mortalities at the time of survey, further suggest that primary hosts/ natural reservoirs currently maintain the disease and that the latter can affect human populations and consequently result in outbreaks if and when relevant conditions including climate, ecological conditions and vector populations, become favourable. Such outbreaks can be further facilitated by the fact that all the three rodent species which harbour plague antibodies were captured from both domestic and wild environments, and hence they are in close contacts with human populations. In fact these species were previously shown to be positive for plague in the neighbouring Mbulu district. The climatic and ecological conditions, socio-cultural and socioeconomic practices as well as rodent and flea fauna in Mbulu and Karatu districts are quite similar (Msangi, 1969; Kilonzo \& Mtoi, 1983). The 100\% infection rate of G. dolichurus is mostly attributable to the fact that only one animal was captured and tested. In fact this species has not been incriminated for involvement in plague endemicity elsewhere in Tanzania (Kilonzo, 1984; 1992; Kilonzo et al. 2000).

The current observations further suggest that plague is endemic in all the surveyed villages in the district and within the Ngorongoro Conservation Area, and that domestic dogs are suitable carriers of the disease, a fact which is consistent with earlier observations in Mbulu, Arusha, Arumeru and Lushoto districts (Kilonzo, 1980; Kilonzo et al. 1993). The absence of plague antibodies in other small carnivores examined can be ascribed to, among other things, the small numbers of specimens tested.

In view of the fairly limited home range of most rodent species and the fact that the villages involved in the current study are far from one another, it is most likely that the presence of plague in such villages is not due to introduction by immigrating reservoirs from the initially affected villages, and that the area harbours a natural focus of the disease.

Despite the presence of $X$. brasiliensis and $D$. lypusus which are reportedly important vectors of plague in the country (Msangi, 1968; Kilonzo \& Mhina, 1983), their population densities were too low to maintain active transmission of the disease in the area. This could, at least partly, be responsible for absence of outbreaks in the district since 1998.

On the basis of the present observations therefore, it is justifiably conclusive that sylvatic plague is endemic in Karatu district and the Ngorongoro Conservation area, and that the disease can break out in the area at any time if and when relevant conditions become favourable. In view of the highly infectious and fatal nature of the disease and the importance of Karatu and Ngorongoro in national and international tourism, it is recommended that effective and sustainable preventive measures are taken in order to prevent occurrence of outbreaks of the disease in the area. It is also recommended that health personnel and authorities in the area should ensure that cases with plague-like symptoms are carefully handled and treated promptly, and that epidemiological surveillance services are strengthened and carried out regularly in order to forecast any outbreak of the disease. In view of the neighbourhood of some of the affected villages to the Lake Manyara National Park and the economic importance of the latter, a similar study at the park is strongly recommended.

On the basis of the present observations therefore, it is justifiably conclusive that sylvatic plague is endemic in Karatu district and the Ngorongoro Conservation area, and that the disease can break out in the area at any time if and when relevant conditions become favourable. In view of the highly infectious and fatal nature of the disease and the importance of Karatu and Ngorongoro in national and international tourism, it is recommended that effective and sustainable preventive measures are taken in order to prevent occurrence of outbreaks of the disease in the area. It is also recommended that health personnel and authorities in the area should ensure that cases with plague-like symptoms are carefully handled and treated promptly, and that epidemiological surveillance services are strengthened and carried out regularly in order to forecast any outbreak of the disease. In view of the neighbourhood of some of the affected villages to the Lake Manyara National Park and the economic importance of the latter, a similar study at the park is strongly recommended. 


\section{Acknowledgements}

We wish to express our sincere gratitude to the Ministry of Health for funding this study; the Sokoine University of Agriculture (SUA) and Tropical Pesticide Research Institute for facilitating the study. We wish to thank Messrs. Salehe M. Msingwa, Joseph M. Assey, Suleiman M. Kinyogoli, Clement M. Pangapanga and Ms Lydia J. Mboya for their technical and field assistance. Thanks are due to Mr. Christopher A. Sabuni and Dr. Abdul Katakweba for carrying out ELISA tests and other laboratory analyses of the specimens. We wish to express our thanks to the NCAA for permission to work in the protected area and financial as well as logistical support. Ms Tecla Sembua is thanked for secretarial services.

\section{References}

Kenya (1978) Plague in Kenya. Health Information Bulletin 2, 1-2. Communicable Disease Centre, Ministry of Health, Nairobi, Kenya.

Kilonzo, B.S. (1977) A simple trap for field collection of adult fleas: studies on its efficiency and simplicity in north-east Tanzania. WHO/VBC/ 77.673. $1-11$.

Kilonzo, B.S. (1980) Studies on determining the involvement of domestic animals in plague epidemiology in Tanzania: (ii) Specific plague antibodies in sera of Canis familiaris, the domestic dog. Tanzania Veterinary Bulletin 2, 56-59.

Kilonzo, B.S. (1981) The origin, dissemination and present status of plague in Tanzania. Dar es Salaam Medical Journal 8,130-142.

Kilonzo, B.S. (1984) Studies on the Present Status of Endemicity, Mammalian Reservoirs and Flea Vectors of Plague in Tanzania. PhD Thesis, University of Dar es Salaam, Tanzania.

Kilonzo, B.S. (1992) Observations on the epidemiology of plague in Tanzania during the period 1974 -1988. East African Medical Journal 69, 494 - 499.

Kilonzo, B.S. (1999) Report on a WHO-sponsored Consultative Investigation of a Suspected Plague Outbreak in Sanje District, Malawi, October, 1999.

Kilonzo, B.S., Gisakanyi, N.D. \& Sabuni, C.A. (1993) Involvement of dogs in plague epidemiology in Tanzania: serological observations in domestic animals in Lushoto District. Scandinavian Journal of Infectious Diseases 25, 503 - 506.
Kilonzo, B.S., Makundi, R.H., Machang'u, R.S., Fadda, C. \& Arntzen, L. (2000) Demonstration of Yersinia pestis DNA and antibodies in humans and animals in Lushoto District: need to improve diagnostic services. Proceedings of the $19^{\text {th }}$ Annual Scientific Conference of the Tanzania Public Health Association, Moshi, November, 2000, pp 172-176.

Kilonzo, B.S. \& Mbise, T.J. (1998) Plague Survey at Karatu, Arusha, August 1998. Unpublished report submitted to the Ministry of Health, Dar es Salaam, September 25, 1998.

Kilonzo, B.S. \& Mhina, J.I.K. (1982) The first outbreak of human plague in Lushoto district, North-east Tanzania. Transactions of the Royal Society Tropical Medicine and Hygiene 76, 172-177.

Kilonzo, B.S. \& Mhina, J.I.K. (1983) Observations on the current status of plague endemicity in the Western Usambara mountains, north-east Tanzania, Acta Tropica, 40, 365-373.

Kilonzo, B.S. \& Msangi, A.S. (1991): Plague: In G.M.R. Mwaluko, W.L. Kilama, M.P. Mandara, M. Murru and C.N.L. Macpherson (eds) Health and Disease in Tanzania. Harper Collins Academic, London and New York. pp. $98-116$.

Kilonzo, B.S. \& Mtoi, R.S. (1983) Entomological, bacteriological and serological observations after the 1977 plague outbreak in Mbulu District, Tanzania. East African Medical Journal 60, 91-97.

Kilonzo, B.S. \& Temu, G.P. (1994) WHO/MOH Consultancy to Investigate the Status of Plague Endemicity in Singida and Lushoto districts, May/June 1994. Unpublished Report.

Leirs, H. (1992) Population Ecology of Mastomys natalensis (Smith, 1834): Multimammate Rats: Possible Implication for Rodent Control in Africa. Ph.D. Thesis, University of Antwerp.

Msangi, A.S. (1968) Observations on the Endemicity of Plague in Tanzania. Ph.D. Thesis, University of Dar es Salaam, Tanzania.

Msangi, A.S. (1969) Entomological observations after the 1968 plague outbreak in Mbulu district, Tanzania. East African Medical Journal 46, 465-470.

WHO (1995) Report of an Inter-regional Meeting on Prevention and Control of Plague, New Delhi, India, 13 - 16 March, 1995. 